\title{
Physicochemical properties of endodontic sealers of different bases
}

Gabriela Alexandra MARÍN-BAUZA ${ }^{1}$, Yara Teresinha Correa SILVA-SOUSA ${ }^{2}$, Suely Aparecida da CUNHA ${ }^{1}$, Fuad Jacob
Abi RACHED-JUNIOR ${ }^{3}$, Idomeo BONETTI-FILHO ${ }^{4}$, Manoel Damião SOUSA-NETO ${ }^{5}$, Carlos Eduardo Saraiva MIRANDA

1- DDS, Postgraduate student, School of Dentistry, University of Ribeirão Preto, Ribeirão Preto, SP, Brazil.

2- DDS, MSc, PhD, Titular Professor, School of Dentistry, University of Ribeirão Preto, Ribeirão Preto, SP, Brazil.

3- DDS, MSc, PhD, Assistant Professor, School of Dentistry, University of Ribeirão Preto, Ribeirão Preto, SP, Brazil.

4- DDS, MSc, PhD, Adjunct Professor, Araraquara School of Dentistry, Univ. Estadual Paulista - UNESP, Araraquara, SP, Brazil.

5- DDS, MSc, PhD, Associate Professor, Ribeirão Preto School of Dentistry, University of São Paulo, Ribeirão Preto, SP, Brazil.

6- MSc, PhD, Adjucnt Professor, University of Ribeirão Preto, School of Pharmaceutics Science, Ribeirão Preto, SP, Brazil.

Corresponding address: Prof. Yara Teresinha Correa Silva-Sousa - Rua Célia de Oliveira Meirelles, 350 - $14024-070$ - Ribeirão Preto - São Paulo - Brasil

- Phone/fax: +55 1636036763 - e-mail: ysousa@unaerp.br

Received: November 3, 2010 - Modification: August 5, 2011 - Accepted: August 31, 2011

\section{ABSTRACT}

O bjective: To assess the setting time (ST), flow (FL), radiopacity (RD), solubility (SB) and dimensional change following setting (DC) of different sealers (AH Plus ${ }^{\circledR}$, Polifil, Apexit Plus ${ }^{\circledR}$, Sealapex ${ }^{\circledR}$, Endométhasone ${ }^{\circledR}$ and Endofill $\left.{ }^{\circledR}\right)$ according to American National Standards Institute/American Dental Association (ANSI/ADA) Specification 57. Material and methods: Five samples of each material were used for each test. For ST, cast rings were filled with sealers and tested with a Gilmore needle. For $\mathrm{FL}$, the sealer was placed on a glass plate. After $180 \mathrm{~s}$, another plate with $20 \mathrm{~g}$ and a load of $100 \mathrm{~g}$ were applied on the material, and the diameters of the discs formed were measured. In RD, circular molds were filled with the sealers, radiographed and analyzed using Digora software. For SB, circular molds were filled with the sealers, a nylon thread was placed inside the material and another glass plate was positioned on the set, pressed and stored at $37^{\circ} \mathrm{C}$. Samples were weighed, placed in water, dried and reweighed. The water used for SB was analyzed by atomic absorption spectrometry. For DC, circular molds were filled with the sealers, covered by glass plates and stored at $37^{\circ} \mathrm{C}$. Samples were measured and stored in water for 30 days. After this period, they were dryed and measured again. Results: Regarding ST, AH Plus ${ }^{\circledR}$, Apexit $^{\circledR}$ and Endofil ${ }^{\circledR}$ sealers are in accordance with ANSI/ADA standards. Endométhasone's manufacturer did not mention the ST; Polifil is an experimental sealer and Sealapex ${ }^{\circledR}$ did not set. Considering RD, SB and DC, all sealers were in accordance with ANSI/ADA. The spectrometric analysis showed that a significant amount of $\mathrm{K}^{+}$and $\mathrm{Zn2}^{+}$ions was released from Apexit Plus ${ }^{\circledR}$ and Endofill ${ }^{\circledR}$, respectively. Conclusion: Except for DC, all other physicochemical properties of the tested sealers conformed to ANSI/ADA requirements.

Key words: Endodontics. Root canal obturation. Root canal filling materials.

\section{INTRODUCTION}

Since the first studies on the prognosis of endodontic therapy, the quality of root canal filling has been considered essential for treatment success ${ }^{22}$. The presence of voids in the root canal filling facilitates bacterial proliferation and the perpetuation of periapical lesions ${ }^{20}$.

Among the several factors that can interfere in the root canal filling, the endodontic sealers stand out $1,3,14,16,17$. These materials should present biocompatibility ${ }^{15,21}$ and suitable antimicrobial ${ }^{28}$ and physiochemical properties ${ }^{5,19}$. In this context, it is important to study the properties of the filling materials in order to establish the appropriate parameters for the development of new products, as well as to evaluate those already available on the market ${ }^{25}$. 
Root canal sealers can be classified according to the chemical composition in zinc oxideeugenol-based, calcium hydroxide-containing, glass-ionomer-based, epoxy-resin-based and methacrylate-resin-based sealers ${ }^{19,24}$.

The zinc oxide-eugenol-based sealers were introduced in endodontics by Grossman, in 1936, to be used in conjunction with the gutta-percha or silver cones in root canal fillings. Endofill (Dentsply-Mallefer, Dentsply Indústria e Comércio Ltda., Petrópolis, RJ, Brazil) and Endométhasone ${ }^{\circledR}$ (Spécialities Septodont, Saint-Maurdes-Fossés, Cedex, France) are commonly used zinc oxideeugenol-based sealers, both available in a powderliquid presentation.

Sealers that contain calcium hydroxide were idealized with the purpose of improving the biological properties and ensuring a good seal of root canal system. Among these products, Apexit Plus $^{\circledR}$ (Ivoclar, Vivadent, Fürstentum, Schaan, Liechtenstein) and Sealapex ${ }^{\circledR}$ (Sybron-Endo, Glendora, CA, USA) are available in the market in a paste-paste presentation ${ }^{26,27}$.

The first resin-based sealer was proposed by Schröeder, in 1954, and contained epoxy resin and bisphenol. Since them, studies have contributed to the improvement of sealers' quality, leading to the development of an epoxy resin-based sealer with good physicochemical properties, $\mathrm{AH}$ Plus $^{\circledR}$ (Dentsply, DeTrey GmbH, Konstanz, Germany) ${ }^{14}$.

Much research has been done to develop products derived from biomaterials, in order to increase the compatibility to biological tissues ${ }^{11-13,18}$. In the 1980's, an experimental sealer, called Polifil, was developed at the Araraquara School of Dentistry (SP, Brazil). This sealer is based on a polyurethane vegetable resin, Ricinus communis extract, and has been demonstrating good flow ${ }^{18}$, efficient sealing capacity ${ }^{13,18}$ and some antimicrobial activity ${ }^{11,12}$.

In 1983, the American National Standards Institute/American Dental Association (ANSI/ $A D A$ ) released a series of norms and tests (named Specification 57) to evaluate the physiochemical properties of endodontic sealers, aiming at standardizing the tests and promote larger scientific quality in the researches. This specification was revised in 2000 and it includes the following tests: film thickness, setting time, flow, radiopacity, solubility and dimensional change following setting ${ }^{2}$.

Due to the diversity of composition of the available sealers and considering the ANSI/ADA standards, the objective of this study was to evaluate in vitro the physiochemical properties of sealers of different bases: Endofill ${ }^{\circledR}$ and Endométhasone ${ }^{\circledR}$ (zinc oxide and eugenol), Apexit Plus ${ }^{\circledR}$ and Sealapex ${ }^{\circledR}$ (calcium hydroxide), Polifil (Ricinus communis polymer) and $\mathrm{AH}$ Plus ${ }^{\circledR}$ (epoxy resin), in order to contribute to the selection of the appropriate material for clinical practice.

\section{MATERIAL AND METHODS}

Setting time, flow, radiopacity, solubility, and dimensional change after setting for $\mathrm{AH}$ Plus ${ }^{\circledR}$, Polifil, Apexit Plus ${ }^{\circledR}$, Sealapex ${ }^{\circledR}$, Endométhasone ${ }^{\circledR}$ and Endofill ${ }^{\circledR}$ sealers were measured according to ANSI/ADA standards for dental root canal sealing materials by one examiner blinded to the identification of the materials. Details of each sealer are displayed in Figure 1.

All tested materials were prepared in accordance to the manufacturers' instructions. AH Plus ${ }^{\circledR}$, III and IV are presented as two pastes and, for each tested sample, $15 \mathrm{~mm}$ of the sealer (1:1) was dispensed onto a mixing pad and mixed until obtaining a homogeneous mixture. In group II (Polifil), 0.18 $\mathrm{mL}$ of the liquid was mixed to $0.44 \mathrm{~mL}$ of the paste, measure through a graduate syringe and the mixture was mixed on a glass plate.

For Endométhasone ${ }^{\circledR}$ and Endofill ${ }^{\circledR}, 3$ drops of the liquid and a portion of the powder were released in glass plate and mixed in a gradual way until getting the ideal consistence, characterized by a cement thread of approximately $2 \mathrm{~cm}$, without falling during $15 \mathrm{~s}$.

For the physicochemical tests, the arithmetic mean of five replicates for each sealer was recorded and considered as the result of the test.

\section{Setting time}

Five plaster of cast rings having an internal diameter of $10 \mathrm{~mm}$ and a thickness of $2 \mathrm{~mm}$ were prepared for each group. The external borders of the moulds were fixed with wax on a glass plate $(75 \times 25 \times 1 \mathrm{~mm})$. The moulds were filled with the material and transferred to a chamber with $95 \%$ relative humidity and a temperature of $37^{\circ} \mathrm{C}$. After $150 \pm 10 \mathrm{~s}$ from the onset of mixing, a Gilmore-type needle with a mass of $100 \pm 0.5 \mathrm{~g}$ having a flat end of $2.0 \pm 0.1 \mathrm{~mm}$ in diameter was carefully lowered vertically onto the horizontal surface of the testing sample. The needle tip was cleaned and the probing was repeated until indentations ceased to be visible. The time used from the start of mixing to this point was recorded. If the results differed by more than $\pm 5 \%$, the test was repeated.

\section{Flow test}

The amount of $0.5 \mathrm{~mL}$ of each sealer tested was placed on a glass plate $(10 \times 10 \times 3 \mathrm{~mm})$ using a graduated disposable $3-\mathrm{mL}$ syringe. At $180 \pm 5$ seconds after the onset of mixing, another plate with a mass of $20 \pm 2 \mathrm{~g}$ and a load of $100 \mathrm{~g}$ were carefully applied on top of the material. Ten min after mixing the cement, the load was removed and the major and minor diameters of the compressed discs were 
measured using a digital calliper with a resolution of $0.01 \mathrm{~mm}$ (Mitutoyo MTI Corporation, Tokyo, Japan). If both measurements were consistent to within 1 $\mathrm{mm}$, the results were recorded. If the major and minor diameter discs were not uniformly circular or did not match within $1 \mathrm{~mm}$, the test was repeated.

\section{Radiopacity test}

Five acrylic plates $(2.2 \mathrm{~cm} \times 4.5 \mathrm{~cm} \times 1 \mathrm{~mm})$, containing four wells measuring $1 \mathrm{~mm}$ in depth and $5 \mathrm{~mm}$ in diameter, were prepared and placed over a glass plate covered by cellophane sheet. In group I, the freshly mixed sealer was introduced into the wells using a syringe, to avoid the formation of bubbles. In groups II, III the respective material applicators were used to fill the wells. Another glass plate covered with cellophane was placed on top until complete setting and any excess sealer removed. Each plate was kept in an incubator $\left(37^{\circ} \mathrm{C}\right.$, $95 \%$ relative humidity) for a period corresponding to three times the setting time. Each well was filled with one of the sealers, following a sequence according to the setting time of the material, from the longest to the shortest, so that the samples would be ready for radiographic evaluation after the final setting of all materials.

Each one of the acrylic plates containing the root filling materials was positioned, at the time of the radiographic exposure, alongside to another acrylic plate $(1.3 \mathrm{~cm} \times 4.5 \mathrm{~cm} \times 1 \mathrm{~mm})$, containing an aluminum stepwedge, made of 1100 alloy, with the thickness varying from 1 to $10 \mathrm{~mm}$, in uniform steps of $1 \mathrm{~mm}$ each. This set of acrylic plates was placed in front of this phosphor plate and a digital radiograph was taken (Digora system, Soredex Orion Corporation, Helsinki, Finland). Care was taken to place the samples next to the aluminum step wedge and in the middle of the phosphor plate. Radiographic images were obtained using the Spectro 70x X-ray machine (Dabi Atlante, Ribeirão Preto, SP, Brazil), at $70 \mathrm{kVp}$ and $8 \mathrm{~mA}$. The objectto-focus distance was $30 \mathrm{~cm}$ and the exposure time was $0.2 \mathrm{~s}$. Exposed imaging plates of the test samples were immediately scanned after exposure (Digora ${ }^{\mathrm{TM}}$ Scanner) and analyzed using Digora ${ }^{\mathrm{TM}}$ for Windows 5.1 software.

\section{Dimensional change following setting}

Five Teflon moulds, prepared for the production of 3.58-mm high cylindrical test bodies measuring $3 \mathrm{~mm}$ in diameter, were placed on a glass plate wrapped with a fine cellophane sheet. The moulds were filled with a slight excess of freshly mixed sealers and a microscope slide, also wrapped in cellophane, was pressed onto the upper surface of the mould. The assembled group was kept firmly joined with a C-shaped clamp and transferred to an incubator $\left(37^{\circ} \mathrm{C}, 95 \%\right.$ relative humidity) left to

\begin{tabular}{|c|c|c|}
\hline Sealers & Composition & Manufacturer \\
\hline AH Plus & $\begin{array}{l}\text { Paste A: Bisphenol-A epoxy resin, Bisphenol-F epoxy } \\
\text { resin, calcium tungstate, zirconium oxide, silica } \\
\text { and iron oxide pigments. Paste B: Dibenzydiamine, } \\
\text { aminoadamante, trycyclodecane- diamine, calcium } \\
\text { tungstate, zirconium oxide, silica and silicone oil. }\end{array}$ & Dentsply, DeTrey, Konstanz, Germany \\
\hline Polifil & $\begin{array}{l}\text { Paste based on trifunctional polyol, synthetic from } \\
\text { Ricinus communis (castor oil) combined to zinc } \\
\text { oxide and calcium carbonate. Liquid: ampoule with } \\
\text { synthesized pre-polymer from diphenylmethane } \\
\text { diisocyanate with free } 20 \% \text { isocyanate. }\end{array}$ & $\begin{array}{c}\text { Experimental-Polifil,Poliquil } \\
\text { Araraquara Polímeros Químicos Ltda, } \\
\text { Araraquara, Brazil }\end{array}$ \\
\hline Apexit Plus & $\begin{array}{l}\text { Calcium hydroxide, calcium oxide, hydrated } \\
\text { collophonium, disalicylate, bismuth hydroxide, bismuth } \\
\text { carbonate, silicon dioxide, phosphoric acid alkyl ester. }\end{array}$ & Ivoclar/Vivadent,Fürstentum, Liechtenstein \\
\hline Sealapex & $\begin{array}{l}\text { Calcium hydroxide, barium sulfate, zinc oxide, titanium } \\
\text { dioxide and zinc stearate. }\end{array}$ & SybronEndo, Glendora, CA, USA \\
\hline Endométhasone & $\begin{array}{c}\text { Zinc oxide, dexamethasone, hydrocortisone acetate, } \\
\text { diode thymol, paraformaldehyde, lead oxide, barium } \\
\text { sufate, magnesium stearate, bismuth subnitrate. } \\
\text { Eugenol. }\end{array}$ & $\begin{array}{c}\text { Spécialities Septodont, Saint-Maurdes- } \\
\text { Fósses, France }\end{array}$ \\
\hline Endofill & $\begin{array}{c}\text { Zinc oxide, hydrogenated resin, bismuth } \\
\text { subcarbonate, barium sulfate, sodium borate. Eugenol } \\
\text { and oil of sweet almonds }\end{array}$ & $\begin{array}{c}\text { Dentsply, Petrópolis Ind. e Com. Ltda, Rio } \\
\text { de Janeiro, Brazil }\end{array}$ \\
\hline
\end{tabular}

Figure 1- Details of the endodontic sealers used in the study 
stand for a period corresponding to three times the setting time. After this period, the flat ends of the moulds, containing the samples, were grinded with 600 grit wet sandpaper. The samples were removed from the mould, measured with a digital caliper, stored in a $50-\mathrm{mL}$ vessel containing 2.24 $\mathrm{mL}$ of distilled and deionized water, and kept in an incubator $\left(37^{\circ} \mathrm{C}, 95 \%\right.$ relative humidity) for 30 days. The sample was then removed from the container, blotted dry on absorbent paper, and measured again for length. The percentage of the dimensional alterations was calculated using the equation: $\frac{L_{30}-L}{L} \times 100$

where $L_{30}$ is the length of the sample after 30 days of storage and $L$ is the initial length of the sample.

\section{Solubility}

A $1.5-\mathrm{mm}$-thick cylindrical Teflon (Polytetrafluoroethylene, DuPont, HABIA, Knivsta, Sweden) mould measuring $7.75 \mathrm{~mm}$ in inner diameter was filled with freshly mixed sealers. The mould was supported by a larger glass plate and covered with a cellophane sheet. An impermeable nylon thread was placed inside the material and another glass plate, also covered with cellophane film, was positioned on the mould and pressed manually in such a way that the plates touched the entire mould in a uniform manner. The assembly was placed in an incubator $\left(37^{\circ} \mathrm{C}, 95 \%\right.$ relative humidity) and left to stand for a period corresponding to three times the setting time. As soon as the samples were removed from the mould, they were weighed three times each in an analytical balance (HM-200; A\&D Engineering Inc., Bradford, MA, USA), and the mean reading recorded.

The samples were suspended by nylon thread and placed two-by-two inside a plastic vessel with a wide opening containing $7.5 \mathrm{~mL}$ of distilled and deionized water, taking care to avoid any contact between them and the inner surface of the container. The containers were sealed and left for 7 days in an incubator $\left(37^{\circ} \mathrm{C}, 95 \%\right.$ relative humidity). After this period, the samples were removed from the containers, rinsed with distilled and deionized water, blotted dry with absorbent paper, and placed in a dehumidifier for $24 \mathrm{~h}$. Afterwards, they were weighed again. The weight loss of each sample, expressed as percentage of the original mass $\left(m \%=m_{i}-m_{f}\right)$, was taken as the solubility of the sealer.

The solution in which the specimens were immersed was analyzed by atomic absorption spectrometry (Perkin Elmer Instruments $\mathrm{GmbH}$, Überlingen, Germany) to quantify the levels of $\mathrm{Na}^{2+}, \mathrm{K}^{+}, \mathrm{Ni}^{2+}$ and $\mathrm{Zn}^{2+}$ ions released in the solution. Merck solutions with 1000 mg/L concentration
(Merck, Darmstadt, Germany) were used to prepare the standard solution of the different metals. Metals' analytical curves were obtained from appropriate dilutions of each respective stock solution. This spectrophotometer is supplied with hollow cathode lamps with different light spectrums exclusively for measuring metallic ions. The obtained solutions were sprayed into the atomic absorption spectrophotometer for ions quantification. The analyses were made in triplicate for each specimen. The arithmetic mean was done and considered as the results of the concentration of $\mathrm{Na}^{2+}, \mathrm{K}^{+}, \mathrm{Zn}^{2+}$ and $\mathrm{Ni}^{2+}$, expressed as $\mu \mathrm{g} / \mathrm{mL}$.

\section{Statistical analysis}

Five specimens from each group were tested and the means were statistically compared. The Kolmogorov-Smirnov showed that the results were consistent with a normal distribution curve. The parametric statistical analysis was performed by one-way ANOVA and Tukey-Kramer post-hoc test) and the significance level was set as 5\% (GraphPad InStat, GraphPad Software Inc., San Diego, CA, USA).

\section{RESULTS}

Table 1 shows the mean values and standard deviations for the physicochemical properties (setting time, flow, radiopacity, dimensional change following setting and solubility) of the tested sealers.

\section{Setting time}

The ANSI/ADA Specification ${ }^{2}$ requires that the setting time of a sealer shall be within $10 \%$ of that stated by the manufacturers. In this study, $\mathrm{AH}$ Plus ${ }^{\circledR}$ and Apexit Plus ${ }^{\circledR}$ are in agreement with ANSI/ADA standards. The manufacturers of Endométhasone ${ }^{\circledR}$ and Endofill ${ }^{\circledR}$ do not mention the setting time of these sealers and Polifil is still in experimental phase. Statistical analysis demonstrated that all sealers displayed mean values statistically different among themselves $(p<0.05)$ and Endométhasone ${ }^{\circledR}$ and Endofill ${ }^{\circledR}$ presented, respectively, the longest and the shortest setting time. The Sealapex ${ }^{\circledR}$ did not set after $168 \mathrm{~h}$ and, for this reason, it was not subjected to the other tests.

\section{Flow test}

The ANSI/ADA Specification ${ }^{2}$ requires that a sealer shall have a diameter of no less than 20 $\mathrm{mm}$ and all groups of this study conformed to the standards. Statistical analysis showed that Endofill ${ }^{\circledR}$ and Apexit Plus ${ }^{\circledR}$ presented the highest mean values $(p<0.05)$ and were statistically similar between themselves. AH Plus ${ }^{\circledR}$ and Polifil presented intermediate values and were statistically similar 
Table 1- Mean values and standard deviation of the physiochemical properties for each sealer

\begin{tabular}{cccccc}
\hline Sealers & $\begin{array}{c}\text { Setting time } \\
(\mathbf{m i n})\end{array}$ & $\begin{array}{c}\text { Flow } \\
(\mathbf{m m})\end{array}$ & $\begin{array}{c}\text { Radiopacity } \\
(\mathbf{m m ~ A l})\end{array}$ & $\begin{array}{c}\text { Dimensional change } \\
(\%)\end{array}$ & $\begin{array}{c}\text { Solubility } \\
(\%)\end{array}$ \\
\hline AH Plus & $579.00 \pm 4.95^{\mathrm{b}}$ & $36.76 \pm 3.04^{\mathrm{b}}$ & $5.97 \pm 0.24^{\mathrm{a}}$ & $1.69 \pm 0.31^{\mathrm{a}}$ & $0.75 \pm 0.41^{\mathrm{a}}$ \\
Polifil & $113.40 \pm 5.13^{\mathrm{d}}$ & $40.07 \pm 0.99^{\mathrm{b}}$ & $3.01 \pm 0.05^{\mathrm{b}}$ & $3.03 \pm 2.49^{\mathrm{a}}$ & $0.37 \pm 3.26^{\mathrm{a}}$ \\
Apexit Plus & $343.40 \pm 5.94^{\mathrm{c}}$ & $49.20 \pm 1.43^{\mathrm{a}}$ & $3.25 \pm 1.41^{\mathrm{b}}$ & $2.28 \pm 2.47^{\mathrm{b}}$ & $1.47 \pm 1.05^{\mathrm{a}}$ \\
Sealapex & $\mathrm{NH}$ & $\mathrm{NP}$ & $\mathrm{NP}$ & $\mathrm{NP}$ & $\mathrm{NP}$ \\
Endométhasone & $644.80 \pm 5.63^{\mathrm{a}}$ & $28.93 \pm 5.90^{\mathrm{a}}$ & $4.34 \pm 1.37^{\mathrm{a}, \mathrm{b}}$ & $2.39 \pm 0.17^{\mathrm{a}}$ & $0.16 \pm 1.10^{\mathrm{a}}$ \\
\hline Endofill & $71.40 \pm 4.10^{\mathrm{e}}$ & $50.86 \pm 3.26^{\mathrm{a}}$ & $4.02 \pm 0.04^{\mathrm{b}}$ & $1.92 \pm 0.47^{\mathrm{b}}$ & $2.50 \pm 1.30^{\mathrm{a}}$ \\
\hline
\end{tabular}

Same letters indicate statistical similarity $(p>0.05)$

$\mathrm{NH}$ : not set; NP: not performed

Table 2- Metallic ions concentration (mg/L) found in the immersion liquid of the solubility test

\begin{tabular}{cccccc}
\hline Metallic ions & AH Plus & Polifil & Apexit Plus & Endométhasone & Endofill \\
\hline $\mathrm{K}^{+}$ & $0.58 \pm 0.36$ & $0.32 \pm 0.12$ & $1.46 \pm 0.92$ & $14.20 \pm 1.72$ & $0.21 \pm 0.04$ \\
$\mathrm{Na}^{+}$ & $3.07 \pm 2.10$ & $\mathrm{ND}$ & $4.63 \pm 2.33$ & $2.88 \pm 1.54$ & $1.28 \pm 0.72$ \\
$\mathrm{Ni}^{+}$ & $<0.6$ & $<0.6$ & $<0.6$ & $<0.6$ & $<0.6$ \\
$\mathrm{Zn}^{+}$ & $<0.2$ & $2.15 \pm 0.10$ & $<0.2$ & $4.55 \pm 0.83$ & $5.72 \pm 2.13$ \\
\hline
\end{tabular}

ND: not determined

between themselves $(p>0.05)$. Endométhasone ${ }^{\circledR}$ exhibited the lowest mean values.

\section{Radiopacity test}

All materials showed radiopacity above the $3 \mathrm{~mm}$ aluminum recommended by ANSI/ADA Specification 57 (2000). AH Plus ${ }^{\circledR}$ presented higher values statistically similar to Endométhasone ${ }^{\circledR} \quad(p>0.05)$ and significantly different from the other groups $(p<0.05)$, Endométhasone ${ }^{\circledR}$ showed intermediate values, statistically similar to the other sealers $(p>0.05)$.

\section{Dimensional change after setting}

ANSI/ADA states that the maximum limit is $1 \%$ for linear shrinkage and $0.1 \%$ for expansion. The dimensional change of all sealers was greater than the values considered acceptable by ANSI/ ADA. AH Plus ${ }^{\circledR}$, Polifil and Endométhasone ${ }^{\circledR}$ were statistically similar among themselves $(p>0.05)$ and were different from the other materials $(p<0.05)$. Apexit Plus ${ }^{\circledR}$ and Endofill ${ }^{\circledR}$ presented the lowest mean values and were statistically similar among themselves ( $p>0.05)$.

\section{Solubility}

A root canal sealer should not exceed $3 \%$ by mass when the solubility of the set material is tested $^{1}$. All sealers are in agreement with ANSI/
ADA standards. Statistical analysis showed that sealers were statistically similar among themselves $(p>0.05)$.

The distilled and deionized water used for the solubility test was analyzed by atomic absorption spectrometry. The amount of ions released in the immersion solution, in each group, is displayed in Table 2. The concentration of $\mathrm{Na}^{+}$ions was higher for Apexit Plus ${ }^{\circledR}$, followed by AH Plus ${ }^{\circledR}$, Endométhasone ${ }^{\circledR}$ and Endofill ${ }^{\circledR}$. The concentration of $\mathrm{Na}^{+}$ions was not determined for Polifil sealer because, even after successive dilutions, the concentration of this ion in the immersion solution was much higher than the concentration of the most concentrated pattern of the analytical curve. For $\mathrm{K}^{+}$ions, the release was higher in Endométhasone, followed by Apexit Plus ${ }^{\circledR}$, AH Plus ${ }^{\circledR}$, Polifil and Endofill ${ }^{\circledR}$. Regarding $\mathrm{Zn}^{2+}$, the highest release was verified for Endofill, followed by Endométhasone and Polifil. For $\mathrm{Ni}^{2+}$ ions, all groups presented concentration inferior to $0.6 \mathrm{mg} / \mathrm{L}$.

\section{DISCUSSION}

The properties of root canal sealers can be divided into the following categories: physicochemical, antimicrobial, and biological. When studying the ideal properties of a filling material, it is possible to establish research parameters for the development of new products and to evaluate those already 
existing on the market ${ }^{24}$, thus achieving better clinical results in clinical practice.

The physiochemical tests conducted in this study were based on the Specification 57 of ANSI/ADA², following the modifications proposed by CarvalhoJúnior, et al. ${ }^{5}$ (2007), who suggested a reduction of $80 \%$ in volume of the test samples dimensions, aiming to contribute to the rational use of endodontic materials without affecting the results. Another modification refers to the radiographic images of the sealers. The images were obtained using the Digora digital system (Digora software for Windows), which requires a shorter exposure time and the operating system captures, processes, stores and measures the images. It also presents a scale that achieves 256 gray levels ${ }^{4}$.

According to the ANSI/ADA, the setting time of a sealer should vary only $10 \%$ in relation to the established by the manufacturer. In the present study, $\mathrm{AH}$ Plus ${ }^{\circledR}$ and Apexit Plus ${ }^{\circledR}$ are in agreement with ANSI/ADA standards. The manufacturers of Endométhasone and Endofill do not mention the setting time of these sealers and Polifil is still in experimental phase, thus, no setting time has been defined yet.

The setting time is primarily a control test on the stable behavior of a product and is dependent on the sealer components, particle size, room temperature, and relative humidity ${ }^{8,17}$. The chemical agents used to promote the radiopacity of Endométhasone ${ }^{\circledR}$ (lead oxide and bismuth subnitrate) and $\mathrm{AH}$ Plus ${ }^{\circledR}$ (zirconium oxide and calcium tungstate) can be responsible for the longer setting time, since these radiopacifying agents have low solubility in water.

Apexit Plus ${ }^{\circledR}$ sealer has calcium oxide in its composition, which is converted into calcium hydroxide when in contact with water, which delay the setting process due to the inclusion of another chemical reaction. Sealapex did not set in the experimental phase of this study (1 week-period), which is in agreement with previous reports ${ }^{1,10}$. The short setting time was reached by Endofill, probably due to the absence of calcium hydroxide and the presence of a single radiopacifying agent on its composition ${ }^{24}$.

ANSI/ADA establishes as $20 \mathrm{~mm}$ the acceptable minimum value for the diameter of the disc formed by the sealer. In this study, all sealers conformed to the ANSI/ADA standards. Other studies confirm these results ${ }^{19,28}$. It is possible to attribute Endofill's higher values in the flow test to the presence of hydrogenated resin on its formula. For Apexit Plus ${ }^{\circledR}$, it is important to highlight the presence of epoxy resin ${ }^{29}$, probably responsible for the increase of sealer viscosity $6,23,24$. For Polifil, it can be speculated that the physiochemical characteristics of the vegetal polymer favored the flow property. The lower values achieved by Endométhasone ${ }^{\circledR}$ could be attributed to the absence of hydrogenated resin or epoxy resin on its composition.

Root canal sealers should also have sufficient radiopacity to allow for a clear distinction between the materials and surrounding anatomic structures and to facilitate the evaluation of the quality of the root fillings, which can be undertaken only through radiographic examination ${ }^{4}$. ANSI/ADA establishes that the radiopacity should be larger or equal of $3 \mathrm{~mm}$ of aluminum. All materials of the present study were in accordance with the ANSI/ADA specification. Previous studies using AH Plus ${ }^{\circledR 4,19,28}$, Sealapex ${ }^{\circledR 9,26}$ and Endofill ${ }^{\circledR 4}$ confirm this result. The difference in the results can be attributed to the radiopacifying agents present in the sealers ${ }^{7}$. $\mathrm{AH}$ Plus $^{\circledR}$ has calcium tungstate and zirconium oxide on its composition. Endométhasone ${ }^{\circledR}$ has lead oxide and bismuth subnitrate ${ }^{4}$.

Dimensional change demonstrates, in percentage, the shrinkage or expansion of the material following setting. ANSI/ADA states that the maximum limit is $1 \%$ for linear shrinkage and $0.1 \%$ for expansion ${ }^{5}$. The dimensional change of all tested sealers was greater than the values considered acceptable by ANSI/ADA.

AH Plus $^{\circledR}$, Endométhasone ${ }^{\circledR}$ and Polifil presented expansion, while Apexit Plus ${ }^{\circledR}$ and Endofill ${ }^{\circledR}$ presented contraction. In other literature reports, expansion was also verified for $\mathrm{AH}$ Plus $^{\circledR 19,28}$ and Endofill6. Polifil also presented expansion possibly due to water sorption by its components (zinc oxide and calcium carbonate) after polymerization. However, this is an experimental sealer and, consequently, the mechanism related to water sorption and diffusion in the matrix is still not completely elucidated. The contraction presented by Apexit Plus ${ }^{\circledR}$ can be attributed to its high solubility, which affected the dimensional stability of the sealer. Endofill ${ }^{\circledR}$ also presented contraction and it lost an equivalent amount of zinc as that of Endométhasone. The zinc found in the immersion solution can be related to the continuous loss of eugenol from the matrix ${ }^{1,14,24}$.

ANSI/ADA ${ }^{2}$ establishes that solubility of sealers should not exceed $3 \%$ by mass. Solubility results of all groups were within ANSI/ADA recommendations. AH Plus ${ }^{\circledR}$, Apexit Plus ${ }^{\circledR}$ and Endofill ${ }^{\circledR}$ had solubilization with mass loss. Polifil and Endométhasone ${ }^{\circledR}$ presented expansion due to water sorption. Previous studies of solubility only found material loss by solubilization of the sealer structure ${ }^{5,14,19,28}$. In this study, the sealers were statistically similar regarding solubility. However, $\mathrm{AH}$ Plus ${ }^{\circledR}$ presented the lowest mean values, probably due to the presence of HEMA in its composition. The highest solubility was presented by Endofill ${ }^{\circledR}$ due to the continuous loss of eugenol from the sealer matrix ${ }^{5}$. 
The analysis of the immersion solutions revealed that overall the sealers presented low levels of metals concentration. The amount $\mathrm{Ni}^{2+}$ ions found was below the level required for quantification, which is a good result. $\mathrm{Zn}^{2+}$ levels were higher for Endométhasone ${ }^{\circledR}$ and Endofill ${ }^{\circledR}$, which is an expected result since they are zinc oxide-eugenolbased sealers.

Further studies should aim for better understanding of physical, mechanical and chemical properties of the endodontic sealers, supporting researchers and clinicians to determine their ideal applicability in specific clinical procedures.

\section{CONCLUSIONS}

Based on the results of this laboratory research, it may be concluded that:

AH Plus ${ }^{\circledR}$, Apexit Plus $^{\circledR}$ and Endofill ${ }^{\circledR}$ sealers are in accordance with ANSI/ADA standards. Endométhasone's manufacturer did not mention the setting time, Polifil is an experimental sealer and Sealapex ${ }^{\circledR}$ did not set;

All tested sealers were in accordance with ANSI/ ADA for flow, radiopacity and solubility;

The dimensional change of all sealers did not fulfill the ANSI/ADA requirements.

\section{REFERENCES}

1- Allan NA, Walton RC, Schaeffer MA. Setting times for endodontic sealers under clinical usage and in vitro condition. J Endod. 2001;27:421-3.

2- American Dental Association. ANSI/ADA Specification $n^{\circ} 57$ Endodontic Sealing Material. Chicago: ADA; 2000.

3- Bodrumlu E, Sumer AP, Gungor K. Radiopacity of a new root canal sealer, Epiphany. Oral Surg Oral Med Oral Pathol Oral Radiol Endod. 2007; 104:58-61.

4- Carvalho-Junior JR, Correr-Sobrinho L, Correr AB, Sinhoreti MA, Consani S, Sousa-Neto MD. Radiopacity of root filling materials using digital radiography. Int Endod J. 2007;40:514-20.

5- Carvalho-Junior JR, Correr-Sobrinho L, Correr AB, Sinhoreti MA, Consani S, Sousa-Neto MD. Solubility and dimensional change after setting of root canal sealers: a proposal for smaller dimensions of test samples. J Endod. 2007;33:1110-6.

6- Carvalho-Junior JR, Guimarães LF, Correr-Sobrinho L, Pécora JD, Sousa-Neto MD. Evaluation of solubility, desintegration, and dimensional alterations of a glass ionomer root canal sealer. Braz Dent J. 2003;14:114-8.

7- Coomaraswamy KS, Lumley PJ, Hofmann MP. Effect of bismuth oxide radiopacifier content on the material properties of an endodontic Portland cement-based (MTA-like) system. J Endod. 2007;33:295-8.

8- Gambarini G, Romeo U, Tucci E, Gerosa R, Nocca G, Lupi A, et al. Cytotoxicity of Epiphany SE endodontic sealer: a comparative in vitro study. Med Sci Monit. 2009;15:PI15-8.

9- Guerreiro-Tanomaru JM, Duarte MA, Gonçalves M, TanomaruFilho M. Radiopacity evaluation of root canal sealers containing calcium hydroxide and MTA. Braz Oral Res. 2009;23:119-23.

10- Ingle J, Newton C, West JG. Obturation of the radicular space. In: Ingle J, Bakland L, editors. Endodontics. Hamilton: BC Decker Inc.; 2002. p.571-668.
11- Leite FR, Ramalho LT. Bone regeneration after demineralized bone matrix and castor oil (Ricinus communis) polyurethane implantation. J Appl Oral Sci. 2008;16:122-6.

12- Leonardo MR, Silva LA, Tanomaru-Filho M, Bonifácio KC, Ito LY. In vitro evaluation of the antimicrobial activity of a castor oilbased irrigant. J Endod. 2001;27:717-9.

13- Martins GR, Carvalho CA, Valera MC, Oliveira L, Buso L, Carvalho AS. Sealing ability of castor oil polymer as a root end filling material. J Appl Oral Sci. 2009;17:220-3.

14- Nunes VH, Silva RG, Alfredo E, Sousa-Neto MD, Silva-Sousa YTC. Adhesion of Epiphany and AH Plus sealers to human root dentin treated with different solutions. Braz Dent J. 2008;19:4650.

15- Onay EO, Ungor $\mathrm{M}$, Ozdemir BH. In vivo evaluation of the biocompatibility of a new resin-based obturation system. Oral Surg Oral Med Oral Pathol Oral Radiol Endod. 2007;104:60-6.

16- Ørstavik D. Materials used for root canal obturation: technical, biological and clinical testing. Endod Topics. 2005;12(6):25-38. 17- Ørstavik D, Nordahl I, Tibballs JE. Dimensional change following setting of root canal sealer materials. Dent Mat. 2001;17:512-9.

18- Pinheiro CR, Guinesi AS, Camargo EJ, Pizzolitto AC, BonettiFilho I. Bacterial leakage evaluation of root canals filled with different endodontic sealers. Oral Surg Oral Med Oral Pathol Oral Radiol Endod. 2009;108:56-60.

19- Resende LM, Rached-Junior FJ, Versiani MA, Souza-Gabriel $A E$, Miranda $C E$, Silva-Sousa $Y T$, et al. A comparative study of physicochemical properties of AH Plus, Epiphany, and Epiphany SE root canal sealer. Int Endod J. 2009;42:785-93.

20- Ricucci D, Lin LM, Spångberg LS. Wound healing of apical tissues after root canal therapy: a long-term clinical, radiographic, and histopathologic observation study. Oral Surg Oral Med Oral Pathol Oral Radiol Endod. 2009;108:609-21.

21- Scarparo RK, Grecca FS, Fachim EV. Analysis of tissue reactions to methacrylate resin-based, epoxy resin-based and oxide-eugenol endodontic sealers. J Endod. 2009;35:229-32.

22- Sjögren ULF, Hagglund B, Sundquist G, Wing K. Factors affecting the long term results of endodontic treatment. J Endod. $1990 ; 16: 498-504$.

23- Sousa-Neto MD, Guimarães LF, Gariba Silva R, Saquy PC, Pécora JD. The influence of different grades of rosins and hydrogenated resins on the powder-liquid ratio of Grossman cements. Braz Dent J. 1998;9:11-8.

24- Sousa-Neto MD, Guimarães LF, Saquy PC, Pécora JD. Effect of different grades of gum rosins and hydrogenated resins on the solubility, disintegration, and dimensional alterations of Grossman cement. J Endod. 1999;25:477-80.

25- Sousa-Neto MD, Passarinho-Neto JG, Carvalho-Júnior JR, CruzFilho AM, Pécora JD, Saquy PC. Evaluation of effect of EDTA, EGTA and CDTA on dentin adhesiveness and microleakage with different root canal sealers. Braz Dent J. 2002;13:123-8.

26- Tanomaru-Filho M, Jorge EG, Guerreiro-Tanomaru JM, Goncalves M. Radiopacity evaluation of new root canal filling materials by digitalization of images. J Endod. 2007;33:249-51. 27- Tanomaru-Filho M, Jorge EG, Tanomaru JMG, Gonçalves M. Evaluation of the radiopacity of calcium hydroxide- and glassionomer-based root canal sealers. Int Endod J. 2008;41:50-3. 28- Versiani MA, Carvalho-Júnior JR, Padilha MI, Lacey S, Pascon EA, Sousa-Neto MD. A comparative study of physicochemical properties of AH Plus and Epiphany root canal sealants. Int Endod J. 2006;39:464-71.

29- Zhou JM, Lucas JP. Hygrothermal effects of epoxy resin. Part I: the nature of water in epoxy. Polymer. 1999;40:5505-12. 